\title{
PEMBERIAN HAK GUNA USAHA DI ATAS TANAH HAK KOMUNAL MENURUT HUKUM PERTANAHAN DI INDONESIA
}

\author{
Ni Ketut Krismanika; I Putu Gede Seputra; Luh Putu Suryani \\ Fakultas Hukum Universitas Warmadewa, Denpasar - Bali, Indonesia
}

\begin{abstract}
Abstrak
Pemberian Sertifikat Hak Komunal dilakukan Menurut Pasal 18 peraturan MATR/KBPN No. 10/2016, apabila sudah diputuskan bahwa oleh Gubernur, Bupati/Walikota di tempat tersebut memang benar terdapat masyarakat adat, maka Pejabat tersebut akan melaporkan ke Kementerian Badan pertanahan Nasional (selanjutnya disingkat BPN) supaya tidak diubah dan dimohonkan pendaftaran Hak Komunal untuk tanahnya yang terdapat di daerah itu. Penelitian ini bertujuan untuk mengetahui mekanisme pemberian sertifikat hak atas tanah komunal persekutuan hukum adat dan juga untuk mengidentifikasi hak guna usaha dengan hak komunal berdasarkan pengaturan agrarian. Penelitian ini merupakan penelitian hukum normatif dengan pendekatan perundangundangan dan pendekatan analisis dan konsep hukum. Hasil penelitian ini menunjukkan bahwa keputusan Menteri Pertanahan mengatakan jika hasil penelitian di tempat itu terdapat masyarakat hukum adat dan tanahnya, pengukuhan penduduk adat diputuskan kementerian MATR/BPN wilayah tersebut agar ditetapkan dan didaftarkan hak komunal atas tanahnya pada BPN wilayah itu. Hak komunal yang dimohonkan itu kedepannya akan di outputkan Sertifikat hak komunal Masyarakat hukum adat. Setelah keluar Sertifikat Hak Komunal dari BPN atas nama masyarakat adat, pemakaian dan penggunaan bisa dikerjasamakan dengan pihak ketiga, dalam hal ini apabila ada pihak yang memohonkan Hak Guna Usaha di atas tanah Hak komunal tersebut, maka masyarakat hukum adat boleh merundingkan dengan pihak pemohon itu, agar mendapatkan keuntungann yanng sama. Simpulannya adalah Mekanisme pemberian sertifikat hak atas tanah komunal persekutuan hukum adat dimulai dari laporan kepala adat ke Bupati/Walikota dan pemberian Hak Guna Bangunan diatas tanah Hak Komunal itu diperbolehkan Hak Komunalan asalkan masyarakat adat mau melepaskan hak tersebut atau menukar dengan tanah lain.
\end{abstract}

Kata Kunci: Hak Guna Usaha, Hak Komunal, Hukum Pertanahan

\begin{abstract}
The granting of Communal Rights Certificates is done according to Article 18 of the MATR / KBPN regulation No. 10/2016, if it has been decided that by the Governor, the Regent / Mayor in that place there are indeed indigenous peoples, the Officer will report to the Ministry of National Land Agency (hereinafter abbreviated as $B P N)$ so that it is not changed and the registration of Communal Rights for the land contained therein in that area. This study aims to determine the mechanism for granting communal land rights certificates for customary law associations and also to identify tenure rights with communal rights based on agrarian arrangements. This research is a normative legal research with a statutory approach and analysis approach and legal concepts. The results of this study indicate that the Decree of the Minister of Land said that if the results of the research there were indigenous peoples and their land, the inauguration of the indigenous peoples was decided by the ministry of MATR / BPN of the region to determine and register communal rights over their land in the region's $B P N$. The communal rights being applied for will be issued in the future the communal rights certificate of the customary law community. After the Communal Rights Certificate is issued from the BPN on behalf of the customary community, the use and use can be cooperated with a third party, in this case if there is a party who is applying for a Cultivation Right on the communal right, then the customary law community may negotiate with the applicant, in order to get the same benefits. The conclusion is that the mechanism for granting communal land rights certificates to customary law associations starts from the report of the customary head to the Regent / Mayor and the granting of Building Use Rights on Communal Rights land is allowed as long as Communal Rights as long as the customary community wants to relinquish these rights or exchange with other land
\end{abstract}

Keywords: Cultivation Rights, Communal Rights, Land Law 


\section{PENDAHULUAN}

Di tengah masyarakat hukum adat, tanah begitu memiliki fungsi yang sangat besar dikarenakan sesuai bentuknya berupa tanah yang apabila dalam kondisi apapun tidak mengalami perubahan, dengan kata lain pasaran tanah tidak pernah mengalami penurunan, dipandang dari segi materi. Tetap dengan kondisi yang semula, apalagi selalu bisa membuat untung jika benar-benar dimanfaatkan dengan baik (Wignjodipoero, 1973).

Tanah yang jika dimanfaatkan dengan baik akan sangat menguntungkan bagi pemiliknya, salah satu contoh tanah yang dimanfaatkan dengan baik sehingga memberikan hasil yang sangat signifikan yaitu sebagai perkebunan, pertanian, dan barhak Komunalan apabila tanah tersebut peruntukannya perumahan ataupun perdagangan barang dan jasa akan sangat menggiurkan di tengah era modern ini karena seiring berkembangnya jaman. Akan tetapi ada juga rakyat yang dirasa merupakan tindakan yang agak sedikit keliru dengan keputusannya yaitu menjual tanah miliknya, karena ingin memperoleh hasil yang instan, ketika Hak Milik itu dialikan Hak Komunal memang penjual mendapatkan hasil yang sangat instan, tetapi perlu diingat juga ketika pengalihan itu rakyat yang menjual tersebut sudah melepaskan Hak Miliknya ke pembeli, artinya penjual tidak memiliki hak apapun lagi mengenai Hak Milik tersebut.

Mengenai rakyat adat yang memiliki tanah belum mempunyai kekuatan hukum yang pasti, dalam UU Pokok Agraria memang tidak dikenal Hak Komunal, disana hanya menyebutkan Hak Ulayat. Yang dimana hak ulayat memang merupakan hak rakyat adat namun tidak bisa dikatakan hak atas tanah. Hak Komunal dan Hak Usaha punya ciri khas yang tidak sama. Hak Komunal punya cakupan yang sedikit jika ada perbandingannya dengan Hak Usaha. Hak Usaha bersifat umum dan pribadi. Wewenang rakyat adat dapat dilihat di sifat umumnya yaitu:

1) Tempat untuk hidupnya berhubungan dengan kegunaan dan cara perawatannya.

2) Keterkaitan rakyat adat dan wilayahnya

3) Perilaku hukum berhubungan dengan wilayahnya

Untuk bagian dari pribadinya Hak Usaha tidak bisa dijadikan sebagai tanah kepunyaan bilamana digunakan dengan adanya UU Pokok Agraria, berbanding terbalik Hak Komunal dalam artinya dikatakan bisa menjadi tanah kepunyaan bersama.

Di bagian Undang-Undang Pokok Agraria, haknya rakyat tradisional di tetapkan dalam psl 3 UU Pokok Agraria. Pasal itu mengatakan dua objek yakni Hak Usaha beserta hak sama dengan masyarakat adat. Pernyataan Hak Komunal belum disebutkan disana. Yang menjadi intinya adalah Undang-undang itu tidak ada yang menata bagian Hak Komunal. Sampai sekarang masih tidak terdapat penataan pasti tentang bagaimana struktur Hak Komunal itu dalam Undang-undang tersebut (Sumardjono, 2016). Tidak sama terkait Pengaturan Menteri Pertanahan yang terbaru tahun 2016, aturan ini diharapkan menjadi solusi dan mempermudah rakyat tradisional mendaftarkan haknya tersebut.

Istilah Hak Komunal tidak dikenal dalam Undang-undang Pokok Agraria. Penetapan mengenai hak atas tanah yang diatur di dalam Pasal 16 dan Pasal 53, Undang-undang Pokok Agraria juga tidak mengatur tentang hak komunal. Disamping berfungsi mendapat kepastian hukum, Sertifikat Hak Komunal juga menjamin bukti mutlaknya suatu pembuktian kepemilikan tanah. Selanjutnya, Menteri mengatakan bahwa investor tetap boleh menginvestasikan diatas tanah hak komunal. Para pembisnis dapat mengkembangkan bisnisnya berdasar Hak Guna Usaha dan Hak Guna Bangunan. Sehingga kepunyaan tetap berada ditangan masyarakat hukum adat, dan pembisnis hanya memperoleh Hak Guna Usaha atau Hak Guna Bangunan. Pengaturan juga ada ditengah Peraturan Menteri Pertanahan bahwa Hak komunal apabila dihasikan kemasyarakat rakyat tradisional sebagaimana apabila sudah didaftarkan. Berdasarkan kejelasan diatas, ada aturan yang terkait adanya Hak Guna Usaha dengan Hak Komunal itu.

Adapun beberapa penelitian terkait yang telah dikaji sebelumnya, seperti Yostina (2016) yang mengkaji tentang Hak Komunal atas Tanah Masyarakat Hukum Adat di Indonesia. Hasil penelitiannya menunjukkan bahwa masih belum adanya perlindungan hukum dalam Peraturan Menteri ini adalah karena Pemerintah masih belum memahami secara penuh hakikat dari hak ulayat itu sendiri sehingga menyamakan begitu saja hak ulayat dengan hak komunal yang keduanya berbeda karakteristiknya. Dan hak atas tanah yang baru yaitu hak komunal atas tanah yang dikeluarkan oleh Kementrian Agraria dan Tata Ruang juga masih tidak menjamin kepastian hukum karena dasar dikeluarkannya hak atas tanah yang baru tidak sesuai dengan apa yang sudah diatur di 
dalam Undang-undang Pokok Agraria yaitu harus dikeluarkan melalui sebuah Undang- undang. Selanjutnya Pascaningtyas (2017) juga mengkaji penelitian serupa tentang pemberian Hak Guna Usaha di atas tanah Hak Komunal menurut Hukum Pertanahan di Indonesia. Hasil penelitiannya menunjukkan bahwa pemberian sertipikat hak komunal bertentangan dengan hukum pertanahan di Indonesia karena hak komunal bukan merupakan obyek pendaftaran tanah. Selain itu, hak komunal tidak bisa dialihkan sehingga pendaftaran hak komunal menjadi hal yang dipaksakan. Sedangkan hak guna usaha tidak dapat diberikan diatas tanah hak komunal. Hak guna usaha hanya dapat diberikan diatas tanah negara, dan menurut pengertiannya hak komunal tidak dapat diklasifikasikan sebagai tanah negara. Nurhakim dkk (2018) juga mengkaji penelitian serupa yang berfokus pada eksistensi Sertipikat Hak Komunal Atas Tanah Masyarakat Hukum Adat di Sektor Kehutanan dan Perkebunan. Hasil penelitiannya menunjukkan bahwa eksistensi Hak Komunal baik UUPA maupun PP Pendaftaran Tanah tidak mengatur sebagai bagian daripada Hak Atas Tanah maupun objek pendaftaran tanah. Begitu juga UU Kehutanan dan UU Perkebunan sebagai UU sektoral pengelolaan tanah di bidang kehutanan dan perkebunan tidak mengatur mengenai pranata Hak Komunal atas Tanah.

Berdasarkan latar belakang dan penelitian terdahulu di atas, penelitian sekarang ini berfokus pada mekanisme pemberian sertifikat hak atas tanah komunal persekutuan hukum adat dan Hak Guna Usaha dengan Hak Komunal berdasarkan pengaturan Agraria.

\section{METODE PENELITIAN}

Penelitian ini menggunaan penelitian hukum normatif dengan pendekatan perundang-undangan dan pendekatan analisis dan konsep hukum. Adapun sumber bahan penelitian ini adalah bahan hukum primer dan sekunder. Bahan hukum primer yang digunakan yaitu 1) Undang-Undang Dasar Negara Republik Indonesia Tahun 1945; 2) Undang-Undang Nomor 5 Tahun 1960 tentang Peraturan Dasar Pokok-Pokok Agraria (Lembaran Negara Republik Indonesia Nomor 104, Tambahan Lembaran Negara Republik Indonesia Nomor 2043); 3) Peraturan Pemerintah Nomor 40 Tahun 1996 tentang Hak Guna Usaha, Hak Guna Bangunan dan Hak Pakai Atas Tanah (Lembaran Negara Republik Indonesia Tahun 1996 Nomor 58); 4) Peraturan Pemerintah Nomor 24 Tahun 1997 tentang Pendaftaran Tanah (Lembaran Negara Republik Indonesia Tahun 1997 Nomor 59); Sumber Bahan Hukum Sekunder. Sedangkan bahan hukum sekunder diperoleh melalui library research yaitu dengan mengkaji bahan bacaan yang ada kaitannya dengan permasalahan. Teknik yang digunakan dalam pengumpulan data yaitu dengan studi kepustakaan. Setelah bahan hukum yang dibutuhkan terkumpul, maka selanjutkan dianalisis secara deskriptif.

\section{HASIL PENELITIAN DAN PEMBAHASAN}

\section{Mekanisme Pemberian Sertifikat Hak Komunal Menurut Hukum Pertanahan di Indonesia}

1) Hak Atas Tanah yang Menjadi Obyek Pendaftaran Tanah Menurut Pengaturan Undang-Undang Hak atas tanah adalah hak yang diberikan kepada pemilik tanah untuk mengolah dan mempergunakan tanah tersebut sehingga pemilik tanah mendapatkan manfaat dari tanah tersebut (Santoso, 2015). Tiap penduduk yang mempunyai tanah, harus ada bukti bahwa dialah yang berhak. Diberikannya bukti kekuatan hukum pasti untuk seluruh orang Indonesia, salah satunya adalah mendaftarkan tanah ke Badan Pertanahan Nasional. Dibawah ini adalah objek pendaftaran tanah sesuai dengan pasal 9 PP No. 99/1997 diantaranya: bidang tanah yang di atas namakan hak milik, hak guna usaha, Hak Guna Bangunan, Hak Pakai; Hak Pengelolaan ; wakaf; serta Hak Tanggungan. Dilihat pernyataan itu, jadi tidak semua type tanah dijelaskan di Undang- undang Pokok Agraria dimana Hak Komunal dijadikan objek permohonan wilayah. Undang-undang Pokok Agraria cuma menata beberapa wilayah yang dijadikan objek permohonan h ialah: Hak Milik, Hak Guna Usaha, Hak Guna Bangunan.

2) Hak Komunal dinyatakan untuk Objek Permohonan Wilayah Berdasarkan Peraturan Menteri No.10/2016

Terlepas dari hal-hal sudah dipaparkan tersebut, bilamana ada sesuatu kepunyaan rakyat tradisional yaitu Hak Komunal dipakai untuk bisa dimohonkan ke Badan Pertanahan Nasional setempat. Hak Komunal atas tanah adalah hak yang dipunyai oleh penduduk adat atau hak bersama yang dimiliki oleh masyrakat adat. Pengaturan Menteri Agraria itu diciptakan oleh Menteri untuk menjawab problematika terkait Hak Komunal harapannya ialah menyerahkan Hak Komunal sebagai bukti 
kepunyaan untuk masyarakat hukum adat. Sebelum dilakukan permohonan daftar ke Badan Pertanahan Nasional, permohonan daftar tanah wajib melewati proses penelitian atau pengenalan lokasi tanah. Seperti itu juga untuk tanah yang yang diproyeksikan ada rakyat tradisional adat. Pasal 10 Peraturan MATR/KBPN No. 10/2016 mengatakan jika hasil perhitungan ada orang-orang adat dan tanahnya disana, selanjutnya memberi informasi kepada Bupati/Walikota atau Gubernur.

3) Sertifikat Hak Komunal Berfungsi Sebagai Pembuktian Mutlak Berdasarkan Pengaturan Menteri Agraria

Fungsi dari permohonan daftar tanah ialah mendapatkan kepastian hukum dan perlindungan untuk pemilik hak untuk bisa dengan gampang membuktikan dirinya pemilik. Pada akhirnya untuk mendapatkan pembuktian mutlak yang tidak bisa diganggu gugat kepastian, jadi pemilik hak nantinya dikasi sertifikat digunakan pembuktian mutlak (Sudiyat, 2007).

\section{Pemberian Hak Guna Usaha di atas Tanah Hak Komunal Menurut Hukum Pertanahan di Indonesia}

1) Karakteristik Hak Guna Usaha Menurut UUPA dan Peraturan Pelaksanaannya

Setiap hak atas tanah mempunyai ciri yang berbeda beda, oleh karena itu Hak Guna Usaha memiliki karakteristik dan ciri yang tidak sama dengan Hak atas lainnya. Hak Guna Usaha bisa keluar karena ada permohonan Hak Guna Usaha dari pemohon kepada Badan Pertanahan Nasional setempat. KeMenterian Badan Pertanahan Nasional Republik Indonesia akan mengeluarkan Surat Keputusan Pemberian Hak (SKPH) jika permohonan itu disetujui oleh KeMenterian BPN setempat (Hajati dkk., 2020).

Sertifikat Komunal Pemberian Hak Guna Usaha diharuskan dicatatkan ke buku tanah pada Badan Pertanahan Nasional Kabupaten/Kota. Hak Guna Usaha dapat terlaksanakan mulai sejak Surat Keputusan pemberian Hak Guna Usaha didaftarkan pada Badan Pertanahan Nasional kabupaten/kota. Tujuan pendaftaran itu bertujuan untuk mohon penerbitan sertifikat untuk kepastian hukum atau tanda bukti kepunyaan pemohon. Yang punya Hak Guna Usaha diberhakan memiliki dan menggunakan objek Hak Guna Usaha itu untuk usaha di jenis usaha bertani, berkebun, bisnis kolam ikan dan berternak. Intinya yang punya Hak Guna Usaha bebas membuat usaha dibidang yang disebutkan diatas tersebut. Menguasai ketentuan pengaturan peraturan perundang-undangan yang berlaku dan kepentingan masyarakat sekitarnya.

2) Hak Guna Usaha Di Atas Tanah Hak Komunal Menurut Undang-Undang Peraturan Dasar Pokok- Pokok Agraria No.5 Th 1960

UUPA menjelaskan jika Hak Guna Usaha Cuma bisa didapatkan dari tanah negara, ini menyebabkan keraguan aturan UUPA terhadap Hak Komunal, maka dari itu agar aturannya tidak ragu dan jelas Menteri Pertanahan membuat aturan MATR/KBPN No. 10/2016 pengaturannya menjelaskan tentang proses awal adanya Hak Komunal sampai keluarnya Sertifikat Hak Komunal tertera atas nama rakyat adat. Hak Komunal pemberian dari Badan Pertanahan Nasional adalah yang sudah berbentuk Sertifikat Hak Komunal yang dikasikan pada rakyat adat ialah masyarakat yang bertempat tinggal selama bertahun tahun di tempat itu, sudah mendapatkan persetujuan dan ditetapkan oleh Bupati/Walikota atau Gubernur.

Dari penjelasan itu dapat disimpulkkan jika tanah itu bukan lagi tanah negara tetapi kini sudah dikuasai oleh rakkyat adat, dengan bukti Sertifikat Hak Komunal yang dikeluarkan oleh Badan Pertanahan Nasional setempat. Dengan penjelasan itu maka Hak Komunal tidak digolongkan jadi tanah negara lagi. Jadi menurut UUPA Hak Guna Usaha diatas tanah Hak Komunal tidak diperbolehkan.

Hak Komunal yang diberikan kepada masyarakat, juga Hak Komunal itu bisa di bisniskan oleh rakyat adat untuk penambahan pemasukan tanah Hak Komunal tersebut. Sehingga rakyat adat mendapatkan pemasukan dari pemanfaatan Hak Komunal itu. Hak Komunal itu boleh dialihkan ke Hak Guna Bangunan dengan catatan bahwa rakyat adat harus melepaskan hak itu, dengan salah satunya penukaran lahan, kompensasi lahan, yang intinya menguntungkan masyarakat adat tersebut tanpa menghilangkan tanah Hak Komunal yang sudah dimiliki itu.

3) Hak Guna Usaha Di Atas Tanah Hak Komunal Menurut Peraturan MATR/KBPN Nomor 10/2016 Penyelesaian dari masalah kekosongan norma yang menjadi perdebatan UUPA selama ini dibijaksanakan dengan keluarnya penataan MATR No.10/2016 sekaligus memberi nafas segar bagi rakyat adat, Penataan ini diharapkan bisa menjawab problematika yang ada saat ini. Penataan ini 
harus bisa diterapkan oleh rakyat adat, dengan memahami terlebih dahulu syarat-syarat yag tersirat dalam aturan itu, Ketua adat diharapkan mampu dan berani memberikan rekomendasi kepemimpinan daerah terkait adanya Hak Komunal di daerahnya tersebut, tetapi dengan catatan bahwa apa yang direkomendasikan itu tidak bertentangan dengan penataan yang dikeluarkan oleh Menteri Pertanahan yang besar harapan mampu menyelesaikan problematika yang ada.

Mengenai Hak Guna Usaha yang menjadi permasalahannya sekarang adalah bisa atau tidakny Hak Guna Usaha di atas tanah Hak Komunal, disini rakyat adat diharapkan sekali memikirkan baik-baik mengenai masalah ini karena Hak Guna Usaha bisa ada ditanah Hak Komunal tergantung dari rakyat adatnya sendiri, apabila rakyat adat mau melepaskan Haknya tersebut maka Hak Guna Usaha bisa diberikan diatas tanah Hak Komunal, apabila rakyat adat tikdak mau melepaskan tanah Hak Komunal tersebut maka Hak Guna Usaha tidak akan pernah ada diatas tanah Hak Komunal, disini rakyat adat harus memikirkan baik- baik keputusan apa yang mau dikeluarkan oleh masyarakat adat apabila mau melepaskan, harus ada tanah yang diberikan oleh pihak ketiga sebagai ganti dari tanah yang dilepaskan, atau adakan perjanjian apabila Tanah tersebut digunakan sebagai tempat usaha maka karyawannyaa atau mendidik generasi penerus dengan memberikan suatu pembelajaran ketrampilan atau skil agar bisa mengurangi angka pengangguran. Oleh karena itu tidak hanya finansial yang diuntungkan ketika Hak Komunal dilepaskan tetapi pembentukan Sumber Daya Manusia juga didapatkan dalam hal ini. Artinya disini tanah yang dilepaskan tersebut bisa memberikan manfaat yang sangat besar bagi kehidupan rakyat adat saat ini maupun dimasa yang akan datang atau masih sangat bermanfaat untuk penerus bangsa yaitu tidak lain adalah kaum milenial, kaum milenial juga setidaknya harus mengetahui apa yang terjadi dalam hal ini, tidak semata-mata setuju dengan keputusan penghulu dan wakil adat. Intinya adalah rakyat adat harus sangat diuntungkan dalam hal ini. Bukan hanya diuntungkan dari finansial tetapi juga diuntungkan dari pembentukan Sumber Daya Manusia.

\section{SIMPULAN DAN SARAN}

\section{Simpulan}

Berdasarkan hasil yang telah dijabarkan di atas, maka dapat disimpulkan bahwa: 1) mekanisme diberikannya Sertifikat Hak Komunal bertentangan dengan UUPA karena UUPA tidak mengatur tentang adanya Hak Komunal, maka dari itu menteri pertanahan mengeluarkan pengaturan yang sangat diharapkan mampu menjadi jalan keluar atau jalan tengah yang bijaksana yaitu dikeluarkannya Peraturan MATR/KBPN No. 10 Tahun 2016 didalam peraturan itu dijelaskan bahwa tanah rakyat adat itu bisa disetipikatkan, mulai dari laporan kepala adat yang melaporkan kepada pemimpin daerah bahwa di daerah tersebut atau di wilayahnya tinggal terdapat tanah yang memang dari dulu dimiliki atau digunakan oleh rakyat adat namun belum mempunyai kepastan hukum yang jelas atau pasti, setelah itu pemimpin daerah membentuk tim IP4T, yang bertugas untuk memastikan kebenaran adanya rakyat adat di wilayah itu atau tidak, apabila ada, Tim yang dibentuk oleh pemimpin daerah itu terdiri oleh Kakan sebagai ketua, Camat dan Lurah/Kades sebagai anggota, ada juga tokoh adat karena dimohon oleh rakyat adat, Lembaga Swadaya Masyarakat dan Instansi yang mengelola Sumber Daya Alam. Tim itu bertugas untuk: menerima permohonan, memastikan manfaat dan guna tanah, ketika semuanya sudah benar dan pasti, tim akan menyampaikan laporan kepada pemimpin daerah dan pemimpin daerah menetapkan rakyat adat dan tanahnya memang ada dalam satu wilayah, dan disampaikan ke KeMenterian Badan Pertanahan Nasional Kabupaten/Kota, dan didaftarkan setelah itu akan terbit Sertifikat Hak Komunal atas nama rakyat Komunal, itulah proses tentang bagaimana sertifikat hak komunal itu dapat diterbitkan. 2) mengenai Hak Guna Usaha diatas tanah Hak Komunal itu bisa dilakukan dengan cara rakyat adat mau melepaskan Hak Komunal itu dengan kesepakatan seluruh rakyat adat dan kesepakatan pihak ketiga. Sehingga disini rakyat adat diharapkan sekali memikirkan baik-baik mengenai masalah ini karena Hak Guna Usaha bisa ada ditanah Hak Komunal tergantung dari rakyat adatnya sendiri, apabila rakyat adat mau melepaskan Haknya tersebut maka Hak Guna Usaha bisa diberikan diatas tanah Hak Komunal, apabila rakyat adat tikdak mau melepaskan tanah Hak Komunal tersebut maka Hak Guna Usaha tidak akan pernah ada diatas tanah Hak Komunal. 


\section{Saran}

Adapun saran-saran yang dapat diberikan yaitu: 1) Mengenai pendaftaran Hak Komunal, sebaiknya masyarakat hukum adat apabila terdapat tanah masyarakat hukum adat yang belum mempunyai kepastian hukum atau belum bersertifikat agar segera mengajukan permohonan kepada bupati/walikota atau gubernur melalui kepala adat atau perwakilan masyarakat yang berada di kawasan tersebut agar tanah masyarakat hukum adat tersebut mempunyai kepastian hukum atau mempunyai sertpikat atas tanah yang kepemilikannya tertera atas nama masyarkat hukum adat itu sendiri. 2) Sebaiknya pemerintah lebih tanggap dan memproses lebih cepat mengenai permohonan dari kepala adat atau wakil dari masyarakat hukum adat terkait dengan laporan tanah masyarakat yang belum mempunyai kepastian hukum atau belum bersertifikat atas nama masyarakat hukum adat yang ada di daerah tersebut atau pemerintah bergerak secara aktif untuk mencari lokasi tanah masyarakat hukum adat yang belum bersertifikat agar tanah yanng dimiliki oleh masyarakat hukum adat memiliki kekuatan hukum yang pasti. Mengenai pemberian Hak Guna Usaha di atas tanah Hak Komunal, sebaiknya harus ada keterkaitan dengan peraturan yang lebih tinggi. Peraturan yang mengatur mengenai hak komunal harus berlandaskan dengan UUPA dan peraturan lebih tinggi lainnya yang terkait dengan Hak Guna Usaha.

\section{DAFTAR PUSTAKA}

Hajati, S., Winarsi, S., Sekarmadji, A., \& Moechtar, O. (2020). Buku Ajar Politik Hukum Pertanahan. Surabaya: Airlangga University Press.

Nurhakim, L. I., Rubiati, B., \& Afriana, A. (2018). Eksistensi Sertipikat Hak Komunal Atas Tanah Masyarakat Hukum Adat di Sektor Kehutanan dan Perkebunan. Bina Hukum Lingkungan, 3(1), 80-93.

Pascaningtyas, R. K. (2017). Pemberian Hak Guna Usaha di Atas Tanah Hak Komunal Menurut Hukum Pertanahan di Indonesia. Universitas Airlangga.

Santoso, U. (2015). Perolehan Hak Atas Tanah. Jakarta: Kencana.

Sudiyat, I. (2007). Hukum Adat Sketsa Asas. Yogyakarta: Liberty.

Sumardjono, M. S. W. (2016). Ihwal Hak Komunal atas Tanah. Digest Epistema, 6(Hukum dan Keadilan Eko-Sosial).

Wignjodipoero, S. (1973). Pengantar dan Asas-asas Hukum Adat. Bandung: Alumni.

Yostina, M. (2016). Hak Komunal atas Tanah Masyarakat Hukum Adat di Indonesia (Analisi Peraturan Menteri Agraria dan Tata Ruang Nomor 9 Tahun 2015 tentang Tata Cara Penetapan Hak Komunal Atas Tanah Masyarakat Hukum Adat dan Masyarakat yang Berada Dalam Kawasan Tertentu). Jurnal Hukum. 